\title{
Variant Human Phosphoribosylpyrophosphate Synthetase
}

\section{Altered in Regulatory and Catalytic Functions}

\author{
Michael A. Becker, Kari O. Raivio, Bohdan Bakay, William B. Adams, and \\ William L. Nyhan, Department of Medicine, Veterans Administration \\ Medical Center, La Jolla, California 92161; Departments of Medicine and \\ Pediatrics, University of California, San Diego, La Jolla, California 92093
}

A B S T RACT An inherited, structurally abnormal and superactive form of the enzyme 5-phosphoribosyl 1-pyrophosphate (PP-ribose-P) synthetase (EC 2.7.6.1) has been characterized in fibroblasts cultured from a 14-yr-old male (S.M.) with clinical manifestations of uric acid overproduction present since infancy. PPribose-P synthetase from the cells of this child showed four- to fivefold greater than normal resistance to purine nucleotide (ADP and GDP) feedback inhibition of enzyme activity and hyperbolic rather than sigmoidal inorganic phosphate $(\mathrm{Pi})$ activation in incompletely dialyzed extracts. Excessive maximal velocity of the enzyme reaction catalyzed by the mutant enzyme was indicated by: enzyme activities twice those of normal at all concentrations of $\mathrm{Pi}$ in chromatographed fibroblast extracts; normal affinity constants for substrates and for the activator, $\mathrm{Mg}^{2+}$; and twofold greater than normal activity per immunoreactive enzyme molecule. The mutant enzyme thus possessed deficient regulatory and superactive catalytic properties, two mechanisms previously demonstrated individually to underlie the excessive PP-ribose-P and uric acid synthesis of affected members of families with superactive PPribose-P synthetases. Increased PP-ribose-P concentration (4-fold) and generation (2.7-fold) and enhanced rates of PP-ribose-P dependent purine synthetic reactions, including purine synthesis de novo, in S.M. fibroblasts confirmed the functional significance of this patient's mutant enzyme.

Diminished stability of the variant PP-ribose-P synthetase was manifested in vitro by increased thermal lability and in vivo by deficiency of enzyme activity at $\mathrm{Pi}$ concentrations $>0.3 \mathrm{mM}$ in hemolysates

This work was presented in part at the American Society for Human Genetics Annual Meeting, Vancouver, B. C., 4-7 October 1978.

Dr. Raivio's present address is Children's Hospital, University of Helsinki, Helsinki 29, Finland.

Received for publication 15 June 1979 and in revised form 6 August 1979. and by an accelerated, age-related decrement in enzyme activity in lysates of erythrocytes separated by specific density. Despite the diminished amount of PP-ribose-P synthetase in the S.M. erythrocyte population, S.M. erythrocytes had increased PPribose- $P$ concentration and increased rates of incorporation of $\left[{ }^{14} \mathrm{C}\right]$ adenine and hypoxanthine into acid-soluble nucleotides during incubation at $1 \mathrm{mM}$ $\mathrm{Pi}$. These findings provided further confirmation of the extent to which PP-ribose-P synthesis is modulated in the normal cell at physiological $\mathrm{Pi}$ concentration by purine nucleotide inhibition of PP-ribose-P synthetase.

The activity and kinetic characteristics of PPribose-P synthetase from fibroblasts of the mother of patient S.M. indicated that this woman was a heterozygous carrier of the enzyme defect expressed in hemizygous manner by her son.

\section{INTRODUCTION}

The high-energy sugar phosphate 5-phosphoribosyl 1-pyrophosphate (PP-ribose-P) ${ }^{1}$ is an intermediate in the synthesis of purine, pyrimidine and pyridine nucleotides. The synthesis of PP-ribose-P from ATP and ribose-5-phosphate (Rib-5-P) is catalyzed by the enzyme PP-ribose-P synthetase (E.C. 2.7.6.1) in a reaction requiring $\mathrm{Mg}^{2+}$ and inorganic phosphate $(\mathrm{Pi})$. Studies of PP-ribose-P production by intact cells $(1,2)$ and analyses of the kinetic characteristics of purified microbial (3-5) and mammalian (6-10) PP-ribose-P synthetases indicate that a substantial number of effector compounds including substrates, inhibitors, activators, and products influence enzyme activity.

\footnotetext{
${ }^{1}$ Abbreviations used in this paper: FGAR, $\alpha-N$-formylglycinamide ribotide; KRPG, Krebs-Ringer phosphate buffer (pH 7.4) with $5.5 \mathrm{mM}$ glucose; $\mathrm{Pi}$, inorganic phosphate; PPribose-P, 5-phosphoribosyl 1-pyrophosphate; Rib-5-P, ribose5-phosphate.
} 
Correlation of the actions of effector compounds on the quaternary structure and activity of the enzyme (11-13) have led to a proposed molecular model (13) for the control of erythrocyte PP-ribose-P synthetase activity and thus for the regulation of PP-ribose-P synthesis in these cells.

Study of inherited abnormalities of human PPribose-P synthetase, in which structurally variant forms of the enzyme with excessive activity lead to increased PP-ribose-P concentration and generation in conjunction with purine nucleotide overproduction and clinical gout $(10,14-20)$, have provided one line of evidence supporting a role for PP-ribose-P in the regulation of the rate of purine synthesis de novo (21-22). Among these abnormal forms of the enzyme, superactive PP-ribose-P synthetases with either diminished sensitivity to feedback inhibition $(16,17)$ or excessive reaction velocity per molecule of enzyme (10) have been described and extensively characterized. To date, the clinical manifestations of all the males bearing superactive forms of this enzyme, the structural gene for which has been mapped on the $\mathrm{X}$-chromosome (23-25), have been restricted to gouty arthritis, uric acid urolithiasis, and/or renal insufficiency first manifested in early adulthood $(15,18,20)$.

In this study, we report the characterization of a superactive form of PP-ribose-P synthetase identified in fibroblasts cultured from a child (S.M.) whose clinical findings and uric acid overproduction, apparent since the first year of life, have been described (26). Our studies provide evidence for both feedback resistance and excessive maximal reaction velocity in the variant enzyme and indicate that the activity of the aberrant form of PP-ribose-P synthetase is abnormally labile in erythrocytes. In addition, correlation of the in vitro kinetic characteristics of the mutant enzyme with the capacity of intact cells from the affected individual to generate PP-ribose-P provides information about the intracellular regulation of PP-ribose-P synthesis.

\section{METHODS}

Materials. $\quad\left[8-{ }^{14} \mathrm{C}\right] \mathrm{Hypoxanthine}(52 \mathrm{mCi} / \mathrm{mmol}),\left[8-{ }^{14} \mathrm{C}\right]-$ guanine $(46 \mathrm{mCi} / \mathrm{mmol}),\left[8^{-14} \mathrm{C}\right]$ adenosine $(55 \mathrm{mCi} / \mathrm{mmol})$, and sodium $\left[{ }^{14} \mathrm{C}\right]$ formate $(59 \mathrm{mCi} / \mathrm{nmol})$ were purchased from Amersham Corp. (Arlington Heights, Ill.). $\left[8^{-14} \mathrm{C}\right]-$ Adenine $(44 \mathrm{mCi} / \mathrm{nmol})$ was a product of New England Nuclear (Boston, Mass.). All unlabeled purine compounds were obtained from Sigma Chemical Co. (St. Louis, Mo.). The dimagnesium salt of PP-ribose-P was purchased from P-L Biochemicals, Inc. (Milwaukee, Wis.), and Rib-5-P, azaserine, and glucose-6-phosphate were obtained from Calbiochem-Behring Corp., American Hoechst Corp. (San Diego, Calif.). Dibutyl phthalate and dimethyl phthalate were products of Matheson, Coleman \& Bell (East Rutherford, N. J.), and Sephadex chromatographic gels were purchased from Pharmacia Fine Chemicals (Piscataway, N. J.). Eagle's minimal essential medium and fetal calf serum were supplied by Grand Island Biologicals (Grand Island, N. Y.).
Tissue culture methods. Fibroblast cultures were initiated from skin biopsy specimens and were propagated as described (27). Strains were derived from: four normal male individuals; patient S.M.; Su.M., the mother of S.M.; and H.B., an adult male with gout whose purine nucleotide and uric acid overproduction is associated with excessive fibroblast and erythrocyte PP-ribose-P synthetase activity (18). Fibroblasts were grown in monolayer to confluence (corresponding to greater than $\sim 1.5 \times 10^{6}$ cells $/ 75 \mathrm{~cm}^{2}$ culture flask) under conditions described (20). For each fibroblast strain, biochemical determinations were made in duplicate on at least three separate occasions between the 6th and 14th passages in culture. Because no evidence was obtained for an influence of passage number on any of the values shown by an individual strain, the results of determinations have been combined for analysis. Frequent biochemical and microbiological assays (performed by Irvine Scientific, Santa Ana, Calif.) failed to demonstrate evidence for mycoplasma contamination of any of the fibroblast strains.

Preparation of fibroblast suspensions. Fibroblasts were removed from the surface of plastic vessels (Falcon Labware, Oxnard, Calif.) by treatment with trypsin and were washed twice as described (20). The supernatant layer from the final wash was then removed by aspiration, and the cells were resuspended at a density of $5-10 \times 10^{6}$ cells $/ \mathrm{ml}$ in Krebs-Ringer phosphate buffer ( $\mathrm{pH} 7.4$ ) with $5.5 \mathrm{mM}$ glucose (KRPG). The suspension was incubated at $37^{\circ} \mathrm{C}$ for $30 \mathrm{~min}$ with shaking in a water bath. During incubation, $100 \mu \mathrm{l}$ of cell suspension was diluted to $1 \mathrm{ml}$ in KRPG containing $0.04 \%$ trypan blue, and this suspension was incubated $5-10 \mathrm{~min}$ before enumeration of the viable cells on a Spencer bright-line hemocytometer (American Optical Corp., Scientific Instrument Div., Buffalo, N. Y.). Except for studies of enzyme activities, all values for determinations made in fibroblasts and described in Results are expressed per million viable cells. Suspensions in which $<90 \%$ of cells were viable were discarded before analysis.

Preparation of fibroblast extracts for enzyme determinations. Trypsin treated, washed fibroblasts were resuspended at a density of $1-2 \times 10^{7}$ cells $/ \mathrm{ml}$ in a buffer at $\mathrm{pH} 7.4$, containing $2 \mathrm{mM}$ sodium phosphate, $10 \mathrm{mM}$ reduced glutathione, and $1 \mathrm{mM}$ tetrasodium EDTA (extraction buffer). Cells were then disrupted by rapid freezing (in licuid nitrogen) and thawing of the suspension three times, after which the fibroblast extract was centrifuged at $48,000 \mathrm{~g}$ for $30 \mathrm{~min}$ at $4^{\circ} \mathrm{C}$ in a Sorvall RC2B refrigerated centrifuge (DuPont Instruments-Sorvall, DuPont Co., Newtown, Conn.). The resulting supernatant layer was then prepared by one of two alternative procedures for measurement of the enzyme activities described below. In the first procedure, the supernatant layer was dialyzed for $2 \mathrm{~h}$ at $4^{\circ} \mathrm{C}$ against $250 \mathrm{vol}$ of extraction buffer before enzyme assay. In the second procedure, $0.4 \mathrm{ml}$ of the supernatant layer was applied to a Sephadex G-25 column ( 15 $\left.\mathrm{cm} \times 1.4 \mathrm{~cm}^{2}\right)$ equilibrated with extraction buffer, and elution was carried out in this buffer at a flow rate of $0.5 \mathrm{ml} / \mathrm{min}$. Material eluting in the void volume of the column was collected for enzyme assay. Protein determinations on cell extracts and on partially purified enzyme preparations (see below) were performed by the method of Lowry et al. (28) with bovine serum albumin as standard.

Partial purification of fibroblast PP-ribose-P synthetase. On several occasions, 1-ml samples of dialyzed fibroblast extracts, prepared from $\sim 5 \times 10^{7}$ normal and S.M. cells, were added to 1.5-ml suspensions of DEAE-cellulose (corresponding to $0.45 \mathrm{~g}$ of preswollen DE52; Whatman Chemicals, Div. W \& R Balston, Maidstone, England) equilibrated with extraction buffer. After incubation at $4^{\circ} \mathrm{C}$ with stirring for $1 \mathrm{~h}$, the suspensions were placed on Whatman No. I filter papers and filtered on Buchner funnels. The gels were 
washed successively with $20 \mathrm{vol}$ each of extraction buffer, $3 \mathrm{mM}$ sodium phosphate buffer ( $\mathrm{pH} 7.4$ ), and $3 \mathrm{mM}$ sodium phosphate buffer with $50 \mathrm{mM} \mathrm{KCl}$ (pH 7.4) (11). PP-ribose-P synthetase was then eluted from the gels by treatment with two 1.5-ml fractions of $50 \mathrm{mM}$ sodium phosphate buffer containing $220 \mathrm{mM} \mathrm{KCl}, 0.3 \mathrm{mM} \mathrm{ATP}, 6.0 \mathrm{mM} \mathrm{MgCl}$, and $1 \mathrm{mM}$ dithiothreitol ( $\mathrm{pH}$ 7.4). The fractions containing eluted enzyme were combined and, after centrifugation at $12,000 \mathrm{~g}$ for $10 \mathrm{~min}$, the clear supernatant layers were dialyzed for $16 \mathrm{~h}$ at $4^{\circ} \mathrm{C}$ against $1,000 \mathrm{vol}$ of extraction buffer. The purifications of PP-ribose-P synthetase achieved with this procedure ranged from 21- to 44-fold for the normal enzyme and from 19- to 46-fold for the S.M. enzyme, respectively. Recoveries of enzyme activity ranged from 66 to $79 \%$.

Biochemical determinations in fibroblasts. The overall rate of the early steps of purine nucleotide synthesis de novo was estimated by measurement of the rate of incorporation of sodium $\left[{ }^{14} \mathrm{C}\right]$ formate into $\alpha-N$-formylglycinamide ribotide (FGAR) in cells blocked in further conversion of this compound by the glutamine antagonist azaserine at a concentration of $0.3 \mathrm{mM}(20,29)$. In previous studies in fibroblasts, results of this method have correlated well with in vivo determinations of rates of purine synthesis de novo $(20$, 27, 30). The generation and extraction of labeled FGAR and separation of FGAR from other labeled compounds were carried out as described $(27,31)$.

Fibroblast PP-ribose-P concentration and generation (20) and activities of hypoxanthine-guanine phosphoribosyltransferase (E.C. 2.4.2.8) (32) and adenine phosphoribosyltransferase (E.C. 2.4.2.7) (33) were measured by previously described isotopic methods. Rates of incorporation of adenine, hypoxanthine, guanine, and adenosine into purine compounds including nucleotides, nucleosides, bases, and nucleic acids were measured using saturating concentrations of the respective ${ }^{14} \mathrm{C}$-labeled compounds as described by Raivio and Seegmiller (34). Although the rate of adenine nucleotide synthesis at saturating concentrations of radioactive adenine has been used as an estimate of the rate of PP-ribose-P synthesis (35) (or PP-ribose-P availability [36]), we have found that PP-ribose-P generation, as defined (20), allows a more accurate estimate of production of this compound, particularly in cells with increased rates of PP-ribose-P synthesis. As shown in Fig. 1, where PP-ribose-P generation and availability are compared in normal fibroblasts and in cells from patient S.M., PP-ribose-P generation (Fig. 1A) and availability (Fig. 1B) were quite comparable in normal cells but showed a greater difference in S.M. fibroblasts. Incorporation of labeled adenine exceeded PP-ribose-P generation in S.M. fibroblasts because, in contrast to the case in normal cells, saturating concentrations of $\left[{ }^{14} \mathrm{C}\right]$ adenine do not deplete intracellular PP-ribose-P concentrations to nearly unmeasurable values during the course of the incubation period. As a result, PP-ribose-P availability slightly overestimates the apparent generation of the compound in these cells and underestimates the total of PP-ribose-P generation and PP-ribose-P concentration.

Activity of PP-ribose-P synthetase in fibroblast extracts and partially purified fibroblast preparations was determined at several concentrations of $\mathrm{Pi}$ using a minor modification of the two-step method described (10). In the first step, in which PP-ribose-P is produced from MgATP and Rib-5-P, concentrations of the substrates were 100 and $200 \mu \mathrm{M}$, respectively. This reduction in substrate concentrations was prompted by the observation that at $\mathrm{Pi}$ concentrations below $2.0 \mathrm{mM}$, considerable substrate inhibition of enzyme activity occurred in the presence of the usual substrate concentrations, $500 \mu \mathrm{M}$ MgATP and $350 \mu \mathrm{M}$ Rib-5-P. At the reduced substrate concentrations, substrate inhibition was not apparent, and the maximal velocities of the enzyme reaction at

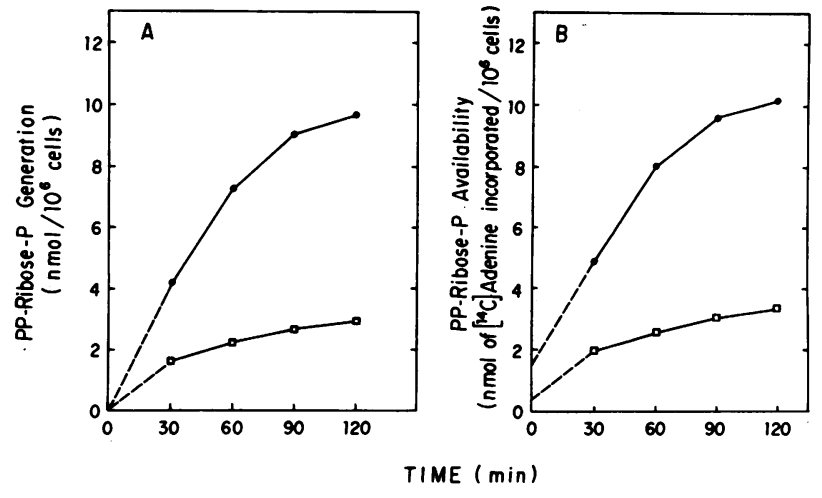

FIGURE 1 PP-ribose-P generation (A) and availability (B) in normal fibroblasts ( $\square$ ) and fibroblasts from patient S.M. (O). Duplicate fibroblast suspensions containing $1.0 \times 10^{6}$ normal or S.M. cells in $400 \mu$ l KRPG were incubated for the appropriate times at $37^{\circ} \mathrm{C}$ with either unlabeled or labeled adenine $(80 \mu \mathrm{M})$. At the points, PP-ribose-P concentrations were determined in cells incubated with unlabeled adenine, and incorporation of ${ }^{14} \mathrm{C}$ into purine compounds was determined in cells incubated with $\left[8-{ }^{14} \mathrm{C}\right]$ adenine. (A) Values indicated were calculated by the formula as described (20), in which PPribose- $P$ concentration at zero $\mathrm{min}$ and at the appropriate incubation time are considered as well as the incorporation of label; in contrast, (B) values shown indicate only incorporation of label (except at zero min, where base-line PP-ribose-P concentrations are plotted).

$\mathrm{Pi}$ concentrations from 2.0 to $32 \mathrm{mM}$ were within $2 \%$ of those measured at the higher substrate concentrations.

For studies of the kinetics of the PP-ribose-P synthetase reaction, the two-step assay was employed, but the reaction mixture for the first step was modified to contain identical concentrations of each of the reactants in $0.2 \mathrm{ml}, 0.1$ of the volume of the standard assay. Studies were carried out at final $\mathrm{Pi}$ concentrations of 1.0 and $32 \mathrm{mM}$. Conditions used for the determination of affinity constants $\left(K_{m}\right)$ and inhibitory constants $\left(K_{1}\right.$ or $\left.I_{0.5}\right)$ were identical to those described elsewhere $(10,18)$ except for appropriate modifications in substrate or inhibitor concentrations.

Thermal inactivation of partially purified fibroblast PPribose-P synthetase was studied at $54^{\circ} \mathrm{C}(10)$. Immunochemical inactivation of PP-ribose-P synthetase in fibroblast extracts prepared by Sephadex G-25 chromatography was investigated by titration of the extracts with the immunoglobulin (Ig)G fraction of monospecific rabbit antiserum to purified normal erythrocyte PP-ribose-P synthetase (19). Measurements of the protein contents of the immunoprecipitates resulting from addition of antiserum to fibroblast extracts were performed as described (10). Mobilities of PP-ribose-P synthetase on cellulose acetate gel were examined with an activity stain (37) after electrophoresis of fibroblast extracts in several buffer systems $(10,24,37)$.

Biochemical determinations in erythrocytes and erythrocyte lysates. Activities of PP-ribose-P synthetase (measured as described above), hypoxanthine-guanine phosphoribosyltransferase (38), adenine phosphoribosyltransferase (30), and glucose-6-phosphate dehydrogenase (E.C. 1.1.1.49) (39) were determined in dialyzed erythrocyte lysates prepared from freshly drawn heparinized venous blood. Erythrocyte PPribose-P (18) and $\mathrm{Pi}$ concentrations (40) were measured after extraction from freshly prepared cells by heating in $\mathbf{5 0}$ $\mathrm{mM}$ Tris- $\mathrm{HCl}, 1 \mathrm{mM}$ EDTA ( $\mathrm{pH}$ 7.4) and by addition of $10 \%$ trichloroacetic acid, respectively. rates of incorporation 
of $\left[{ }^{14} \mathrm{C}\right]$ adenine and $\left[{ }^{14} \mathrm{C}\right]$ hypoxanthine into purine nucleotides (34) were determined after incubation of intact erythrocytes in isotonic saline solutions at $\mathrm{pH} 7.4$ containing 1 and $32 \mathrm{mM} \mathrm{Pi}$.

On two occasions, erythrocytes of four specific density classes were prepared from heparinized blood by means of a two-stage centrifugation procedure described in detail elsewhere (41). Correspondence of the least dense cells with the youngest erythrocytes and the most dense cells with the oldest has previously been established $(41,42)$. Erythrocytes in each density class were washed three times with $20 \mathrm{mM}$ Tris- $\mathrm{HCl}, 150 \mathrm{mM} \mathrm{NaCl}(\mathrm{pH} 7.4)$ and then prepared for measurements of PP-ribose-P concentration and activities of the enzymes listed above.

On a single occasion, normal and S.M. erythrocyte PPribose-P synthetases were partially purified (60- and 44-fold, respectively) by means of the DEAE-cellulose batch elution step described by Fox and Kelley (11). These preparations were used to study kinetic properties of the respective enzymes.

\section{RESULTS}

PP-ribose-P metabolism and purine nucleotide synthesis in S.M. fibroblasts. Comparative values for PP-ribose-P metabolism and purine nucleotide syn- thesis in cultured fibroblasts derived from patient S.M. and from normal individuals are shown in Table I. An increased rate of PP-ribose-P synthesis in the cells of patient S.M. was indicated by the increased intracellular PP-ribose-P concentration and rate of generation (Fig. 1A) shown by these cells. The resulting increased availability of PP-ribose-P (Fig. 1B) for the pathways of purine base salvage and purine nucleotide synthesis de novo was reflected by increased rates of incorporation of labeled hypoxanthine and guanine as well as adenine into purine compounds and by an increased rate of incorporation of $\left[{ }^{14} \mathrm{C}\right]$ formate into FGAR in the presence of azaserine. In contrast with the accelerated rates of incorporation of labeled precursors into purine compounds through PP-ribose-Pdependent biosynthetic pathways shown by S.M. fibroblasts, rates of $\left[{ }^{14} \mathrm{C}\right]$ adenosine incorporation were nearly identical in S.M. and normal fibroblasts. These results suggested that the increased rate of intracellular PP-ribose-P synthesis underlay the excessive rate of purine synthesis de novo in patient S.M. fibroblasts.

TABLE I

PP-ribose-P Metabolism and Purine Nucleotide Synthesis in Fibroblasts Cultured from Four Normal Individuals and from Patient S.M.

\begin{tabular}{|c|c|c|c|c|c|c|c|c|c|c|}
\hline \multirow{3}{*}{$\begin{array}{c}\text { Cell } \\
\text { strain }\end{array}$} & \multirow{2}{*}{\multicolumn{2}{|c|}{ PP-ribose-P }} & \multirow{3}{*}{$\begin{array}{c}\text { FGAR } \\
\text { accumulation }\end{array}$} & & & & & \multicolumn{3}{|c|}{ Fibroblast extract enzyme activity } \\
\hline & & & & \multicolumn{4}{|c|}{ Rate of incorporation of ${ }^{14} \mathrm{C}$} & \multirow[b]{2}{*}{$\begin{array}{l}\text { PP-ribose-P } \\
\text { synthetase }\end{array}$} & \multirow{2}{*}{$\frac{\text { Hyp-Gua }}{\begin{array}{c}\text { Phosphor } \\
\text { transfe }\end{array}}$} & Ade \\
\hline & Concentration & Generation & & Ade & Hyp & Gua & Ado & & & $\begin{array}{l}\text { osyl- } \\
\text { se }\end{array}$ \\
\hline & nmol/10 $0^{6}$ cells & $\mathrm{nmol} / \mathrm{h} / 10^{6} \mathrm{cells}$ & cpm/h/10 cells & \multicolumn{4}{|c|}{$\mathrm{nmol} / \mathrm{h} / 10^{6} \mathrm{cells}$} & \multicolumn{3}{|c|}{ nmol/h/mg protein } \\
\hline \multicolumn{11}{|l|}{ Normal } \\
\hline W.O. & 0.37 & 2.76 & 2,600 & 2.97 & 1.41 & 1.92 & 2.74 & 448 & 126 & 210 \\
\hline L.E.O. & 0.35 & 2.21 & 2,220 & 2.42 & 1.23 & 1.71 & 2.81 & 412 & 138 & 196 \\
\hline M.G. & 0.42 & 3.14 & 3,140 & 3.47 & 1.44 & 1.64 & 3.59 & 464 & 147 & 188 \\
\hline O.N. & 0.29 & 2.48 & 2,550 & 2.71 & 1.36 & 1.68 & 2.27 & 380 & 131 & 218 \\
\hline \multicolumn{11}{|l|}{ Patient } \\
\hline S.M. & 1.69 & 7.34 & 7,240 & 8.15 & 2.76 & 4.73 & 2.66 & 922 & 133 & 211 \\
\hline
\end{tabular}

Fibroblasts were resuspended at cell densities of $5-10 \times 10^{6} / \mathrm{ml}$ in $\mathrm{KRPG}$ and incubated at $37^{\circ} \mathrm{C}$ for $30 \mathrm{~min}$ before determination of PP-ribose-P concentration and generation, rate of purine synthesis de novo (FGAR accumulation) and rates of incorporation of labeled purine bases and adenosine. For measurement of PP-ribose-P concentration, $0.2-0.4 \mathrm{ml}$ of cell suspension was centrifuged for $5 \mathrm{~min}$ at $1,400 \mathrm{~g}$, and the cell pellet was resuspended in $0.3 \mathrm{ml} 50 \mathrm{mM}$ Tris- $\mathrm{HCl}$, $1 \mathrm{mM}$ EDTA ( $\mathrm{pH}$ 7.4) before extraction of PP-ribose-P by heating the $6 \times 50$-mm test tube in boiling water for $45 \mathrm{~s}$. For measurement of rates of incorporation of labeled compounds, 0.2-0.4 ml of cell suspension was incubated in KRPG with the appropriate labeled base (each at a final concentration of $80 \mu \mathrm{M}$ ) or adenosine $(50 \mu \mathrm{M})$ for $60 \mathrm{~min}$ at $37^{\circ} \mathrm{C}$ before addition of perchloric acid to a final concentration $0.4 \mathrm{~N}$. After neutralization of the extract, purine compounds were separated as described (34) and counted. FGAR accumulation was measured after extraction and separation of this compound $(27,31)$ from 1 to $2 \times 10^{6}$ cells incubated for $60 \mathrm{~min}$ at $37^{\circ} \mathrm{C}$ in KRPG with $4 \mathrm{mM} \mathrm{L-glycine,} 20 \mathrm{mM}$ L-glutamine, 1.27 $\mathrm{mM}$ sodium $\left[{ }^{14} \mathrm{C}\right]$ formate, and $0.3 \mathrm{mM}$ azaserine as described $(20)$.

For determination of enzyme activities, fibroblasts were resuspended at cell densities of $1-2 \times 10^{7} / \mathrm{ml}$ in $2 \mathrm{mM}$ sodium phosphate, $10 \mathrm{mM}$ reduced glutathione, and $1 \mathrm{mM}$ EDTA (pH 7.4) before repeated (three times) freezing in liquid nitrogen and thawing. After centrifugation of the cell extract at $48,000 \mathrm{~g}$ for $30 \mathrm{~min}$, the resulting supernatant layer was dialyzed for $2 \mathrm{~h}$ against the extraction buffer. Activities of hypoxanthine-guanine and adenine phosphoribosyltransferases were measured at saturating substrate concentrations using the appropriate $\left[{ }^{14} \mathrm{C}\right]$ purine base as described $(32,33)$. PP-ribose-P synthetase activity was determined with a modified two-step assay (10) in which Pi, MgATP and Rib-5-P concentrations were $32 \mathrm{mM}, 100 \mu \mathrm{M}$, and $200 \mu \mathrm{M}$, respectively. 
PP-ribose-P synthetase in S.M. fibroblasts. An enzymatic basis for the increased rate of PP-ribose-P production in S.M. fibroblasts was provided by the results of determinations of PP-ribose-P synthetase activity in extracts of fibroblasts cultured from this child. S.M. PP-ribose-P synthetase activity, measured at saturating substrate and optimal cofactor concentrations, was twice that found in extracts of normal fibroblasts (Table I). In studies in which activities of PP-ribose-P synthetase were determined (at $32 \mathrm{mM}$ $\mathrm{Pi}$ ) in fibroblast extracts prepared from cultures harvested at cell densities ranging from 0.7 to 3.6 $\times 10^{6} /$ flask, the magnitude of the excessive PP-ribose-P synthetase activity in fibroblasts from patient S.M. was less than that observed in cells from patient H.B. whose superactive enzyme shows increased maximal reaction velocity per enzyme molecule (10). Nevertheless, enzyme activities in S.M.'s cells exceeded those in normal fibroblasts by at least twofold at each cell density. The greater PP-ribose-P synthetase activity in S.M. extracts is not, therefore, a result of variation in enzyme activity with culture density (43).

Activation by Pi of S.M. and normal PP-ribose-P synthetases in partially dialyzed fibroblast extracts is shown in Fig. 2A. In addition to greater enzyme specific activity in S.M. fibroblast extracts, there were distinct differences in the shapes of the Pi activation curves (Fig. 2A, inset). In contrast with the sigmoidal $\mathrm{Pi}$ activation curve of the normal enzyme in incompletely dialyzed (or crude undialyzed) extracts, hyperbolic activation of S.M. PP-ribose-P synthetase was apparent. At $32 \mathrm{mM} \mathrm{Pi}$, S.M. PP-ribose-P synthetase specific activity was 2-fold greater than normal, whereas in the more physiologic range of $\mathrm{Pi}$ concentrations $(\sim 0.5-2 \mathrm{mM})$, S.M. PP-ribose-P synthetase activities were nearly 10 -fold greater than normal. The sigmoidal shape of the normal $\mathrm{Pi}$ activation curve of PP-ribose-P synthetase in crude or incompletely dialyzed extracts results from greater efficiency of feedback inhibitors of enzyme activity at lower Pi concentrations $(1,16)$. Thus, these studies suggested diminished responsiveness of S.M.'s enzyme to feedback inhibitors. In contrast with a described $(14,17)$ feedback-resistant human PP-ribose-P synthetase, however, S.M. PP-ribose-P synthetase showed significantly greater activity than normal at high as well as low $\mathrm{Pi}$ concentrations. This finding thus raised the additional possibilities of increased maximal reaction velocity and/or increased quantity of enzyme per cell to explain the increased activity of S.M. PP-ribose-P synthetase. To assess each of these potential mechanisms for excessive enzyme activity, procedures more effective than dialysis in removing small molecule inhibitors from the milieu of the enzyme were undertaken. Chromatography of crude fibroblast extracts on Sephadex G-25 resulted in hyperbolic $\mathrm{Pi}$ activation curves for
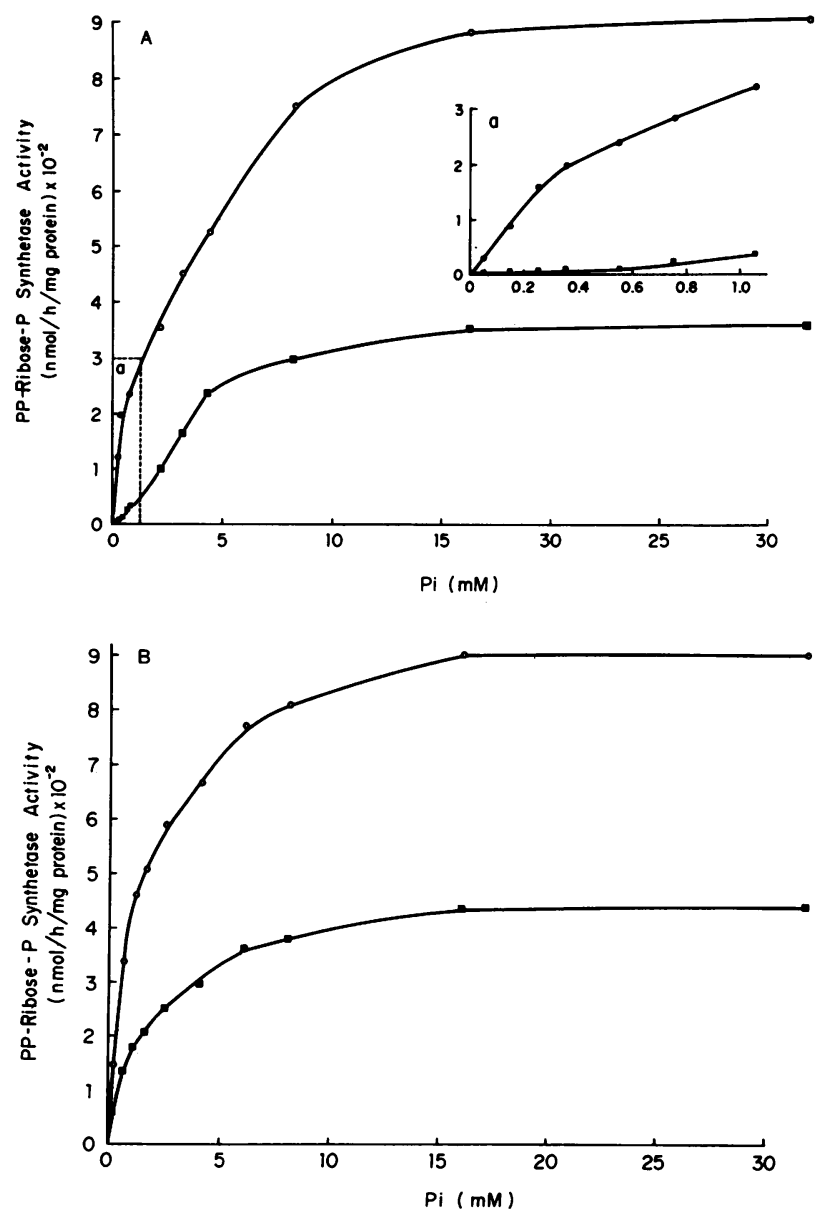

FIgURE 2 Activation of normal ( $\square$ ) and SM (O) fibroblast $\mathrm{PP}$-ribose-P synthetases by $\mathrm{Pi}$ in (A) incompletely dialyzed extracts and (B) extracts chromatographed on Sephadex G-25. In $A$, inset shows enzymes activities over the range from 0.05 to $1.05 \mathrm{mM} \mathrm{Pi}$ in greater detail.

both normal and S.M. PP-ribose-P synthetases, and the variant form of the enzyme exhibited twofold greater activities at all $\mathrm{Pi}$ concentrations (Fig. 2B). Partially purified preparations of normal and S.M. PPribose-P synthetases also showed hyperbolic $\mathrm{Pi}$ activation patterns with a constant relative difference between normal and S.M. enzyme activities when the preparations were studied in the absence of inhibitor compounds.

To determine whether the increased enzyme activity apparent in S.M. fibroblast extracts resulted from an increased number of enzyme molecules or from an enzyme with increased catalytic activity per molecule of enzyme, normal and S.M. fibroblast extracts, prepared by Sephadex G-25 chromatography and equated for protein concentration, were titrated with the IgG fraction of rabbit antiserum to normal erythrocyte PP-ribose-P synthetase (Fig. 3). At each point on the titration curve, inactivation of S.M. PP-ribose-P 


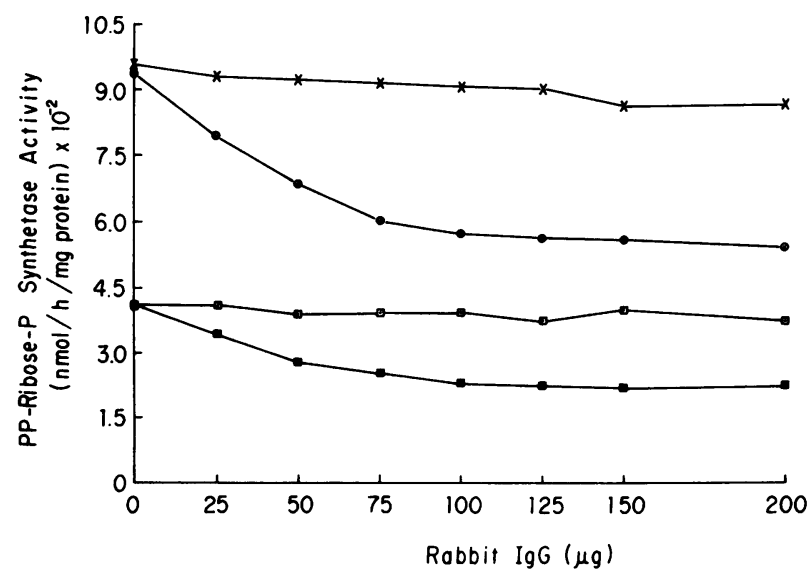

FIGURE 3 Inactivation of normal and SM fibroblast PPribose-P synthetases by rabbit IgG. Normal and SM fibroblast extracts were prepared by Sephadex G-25 chromatography and were equated for protein concentration. Each extract was then titrated with increasing quantities of IgG purified from the sera of an unimmunized rabbit and a rabbit immunized with highly purified normal erythrocte PPribose-P synthetase (19). Incubation mixtures of $100 \mu$ l contained the following: chromatographed fibroblast extract ( $25 \mu \mathrm{g}$ of protein); sodium phosphate buffer ( $\mathrm{pH} 7.4$ ), $2 \mu \mathrm{mol}$; $\mathrm{NaCl} 10 \mu \mathrm{mol}$; reduced glutathione, $0.33 \mu \mathrm{mol}$; EDTA, 0.03 $\mu \mathrm{mol}$; and an amount of rabbit IgG as indicated. After incubation for $30 \mathrm{~min}$ at $37^{\circ} \mathrm{C}$ and $30 \mathrm{~min}$ at $0^{\circ} \mathrm{C}, 75 \mu \mathrm{l}$ of the incubation mixture was assayed for PP-ribose-P synthetase activity at $32 \mathrm{mM} \mathrm{Pi}$. Normal extract incubated with: unimmunized IgG, (๑); immunized IgG, (ם). S.M. extract incubated with: unimmunized IgG, $(\times)$; immunized IgG $(\odot)$.

synthetase was twofold greater than that of the normal enzyme even though, in parallel incubations, protein content of the immune precipitates resulting from addition of antibody to either of the extracts was identical for each ratio of antibody to enzyme. (Residual enzyme activities in the titration curves reflect activity of PP-ribose-P synthetase in the enzyme-antibody complex as previously demonstrated [25].) Thus, similar quantities of PP-ribose-P synthetase were present in normal and S.M. fibroblast extracts, but S.M. fibroblast PP-ribose-P synthetase had twofold greater catalytic activity per immunoreactive enzyme molecule.

Experiments were next undertaken to delineate the substrate binding and inhibitor responsiveness of partially purified normal and S.M. fibroblast PPribose-P synthetases (Table II). Apparent binding constants $\left(K_{m}\right)$ for MgATP, Rib-5-P, and $\mathrm{Mg}^{2+}$ were similar for normal and S.M. enzymes studied at either $1 \mathrm{mM}$ or $32 \mathrm{mM} \mathrm{Pi}$. In contrast, the concentrations $\left(\mathrm{I}_{0.5}\right)$ of ADP and GDP at which $50 \%$ inactivation of PP-ribose-P synthetase was observed were distinctly different for S.M. and normal enzymes. S.M. enzyme was more resistant than normal enzyme to inactivation by $\mathrm{ADP}$ and GDP at $1 \mathrm{mM}$ and $32 \mathrm{mM}$ Pi. Fig. $4 \mathrm{~A}$ and $4 \mathrm{~B}$ show that with increasing $A D P$ and GDP concentration, normal PP-ribose-P synthetase was four- to fivefold more sensitive to these inhibitors at $1 \mathrm{mM}$ $\mathrm{Pi}$ than was the variant enzyme. At $32 \mathrm{mM} \mathrm{Pi}$ the $K_{\mathrm{i}}$ slope for inhibition of the normal enzyme by ADP was $22 \mu \mathrm{M}$ compared to $80 \mu \mathrm{M}$ for the enzyme from patient S.M. These findings indicated that despite normal affinities for substrates, S.M. PP-ribose-P synthetase was relatively more resistant than normal enzyme to the inhibitory effects of nucleotide compounds. Thus, the variant enzyme showed altered regulatory properties with respect to inhibitors as well as increased maximal reaction velocity when studied in the absence of negative effectors.

Thermal inactivation of S.M. PP-ribose-P synthetase at $54^{\circ} \mathrm{C}$ was substantially more rapid than that of normal fibroblast enzyme (Fig. 5) suggesting decreased stability of the variant enzyme. Electrophoretic mobilities of normal and S.M. PP-ribose-P synthetases were identical on cellulose acetate gel in several buffer systems over a range of $\mathrm{pH}$ from 7.5 to 9.0 .

PP-ribose-P synthetase in S.M. erythrocytes. In contrast with the increased specific activity of S.M. PP-ribose-P synthetase in fibroblast extracts (Fig. 2A and B), PP-ribose-P synthetase activities in dialyzed or chromatographed erythrocyte lysates from this patient were considerably lower than those in similarly prepared hemolysates from normal individuals, measuring $<10 \%$ of the mean activities in normal hemolysates at $\mathrm{Pi}$ concentrations $>1 \mathrm{mM}$ (Fig. 6). Despite the apparent deficiency in S.M. erythrocyte enzyme activity, PP-ribose-P synthetase in hemolysates from this patient showed hyperbolic $\mathrm{Pi}$ activation similar to that observed in his fibroblast preparations and, at the lowest $\mathrm{Pi}$ concentrations tested, enzyme activity in partially dialyzed S.M. hemolysates slightly exceeded those in comparably prepared hemolysates from normal individuals (Fig. 6, inset).

Several possible explanations for these findings were investigated. First, mixtures of normal and S.M. hemolysates failed to provide evidence for differences between these extracts in the content of either inhibitors or activators of PP-ribose-P synthetase. Second, under conditions of incubation with $\mathrm{Pi}, \mathrm{Mg}^{2+}$, and MgATP previously established to promote aggregation of normal PP-ribose-P synthetase subunits to active polymers (13), stimulation of S.M. and normal PP-ribose-P synthetase activities were proportionally similar. In addition, the elution profiles of normal and S.M. PP-ribose-P synthetase activities from Sephadex G-200 after chromatography of erythrocyte lysates were identical. Thus, the lower specific activity of the S.M. erythrocyte enzyme did not appear to result from an altered state of subunit aggregation.

To investigate the possibility that instability of S.M. PP-ribose-P synthetase might account for the observed deficit in erythrocyte enzyme activity, fractionation of normal and S.M. erythrocytes by specific density was carried out using the dimethyl phthalate-dibutyl phthal- 
TABLE II

Comparison of Kinetic Constants of Purified Normal and S.M. Fibroblast PP-ribose-P Synthetases

\begin{tabular}{|c|c|c|c|c|c|c|c|c|}
\hline \multirow[b]{2}{*}{ Effector } & \multirow{2}{*}{$\begin{array}{c}\text { Variable } \\
\text { substrate }\end{array}$} & \multirow{2}{*}{$\begin{array}{c}\mathrm{Pi} \\
\text { concentration }\end{array}$} & \multicolumn{3}{|c|}{ Normal enzyme } & \multicolumn{3}{|c|}{ S.M. enzyme } \\
\hline & & & $K_{\mathrm{m}}$ & $I_{0.5}$ & $K_{i}$ slope & $K_{\mathrm{m}}$ & $\mathrm{I}_{0.5}$ & $K_{\mathrm{i}}$ slope \\
\hline & & $m M$ & & & $\mu M$ & & & \\
\hline \multicolumn{9}{|l|}{ Substrates } \\
\hline \multirow[t]{2}{*}{ MgATP } & MgATP & 1 & 16 & - & - & 15 & - & - \\
\hline & & 32 & 24 & - & 一 & 22 & - & - \\
\hline \multirow[t]{2}{*}{ Rib-5-P } & Rib-5-P & 1 & 12 & - & - & 15 & - & - \\
\hline & & 32 & 27 & - & - & 33 & - & - \\
\hline \multicolumn{9}{|l|}{ Activator } \\
\hline \multirow[t]{2}{*}{$\mathrm{Mg}^{2+}$} & MgATP & 1 & 36 & - & - & 32 & - & - \\
\hline & & 32 & 44 & - & - & 49 & - & - \\
\hline \multicolumn{9}{|l|}{ Inhibitors } \\
\hline \multirow[t]{2}{*}{ ADP } & MgATP & 1 & - & 22 & - & - & 85 & - \\
\hline & & 32 & - & 135 & 22 & 1 & 280 & 80 \\
\hline \multirow[t]{2}{*}{ GDP } & MgATP & 1 & - & 34 & - & - & 153 & - \\
\hline & & 32 & - & 320 & - & - & $>750$ & - \\
\hline
\end{tabular}

Normal and S.M. PP-ribose-P synthetases, purified $\sim 30$-fold, were studied at $1 \mathrm{mM}$ and 32 $\mathrm{mM}$ Pi. For studies of affinity constants $\left(K_{\mathrm{m}}\right)$, incubation mixtures of $0.2 \mathrm{ml}$ contained the components of the standard reaction mixture at the usual concentrations except that when MgATP was the variable substrate, concentrations of MgATP ranged from 0 to $100 \mu \mathrm{M}$, and when Rib-5-P was the variable substrate, concentrations of this compound ranged from 0 to 350 $\mu \mathrm{M}$. When binding of magnesium was studied, the concentration of $\mathbf{M g C l}_{2}$ was varied from 0.1 to $5.0 \mathrm{mM}$ in excess of the variable MgATP concentration. Affinity constants and the inhibitory constant $\left(K_{\mathrm{i}}\right)$ for ADP were determined as described (10). For the latter determination MgATP concentrations were varied from 0 to $100 \mu \mathrm{M}$ in the presence of fixed ADP concentrations ranging from 0 to $100 \mu \mathrm{M}$. Additional inhibitory constants $\left(I_{0.5}\right)$ were calculated from studies in which increasing concentrations of ADP and GDP were added to the first step of standard incubation mixtures (MgATP and Rib-5-P concentrations, 100 and $200 \mu \mathrm{M}$, respectively) for measurement of PP-ribose-P synthetase activity at either $1 \mathrm{mM}$ or $32 \mathrm{mM} \mathrm{Pi}$. Inhibitor concentrations ranged from 0 to $250 \mu \mathrm{M}$ at $1 \mathrm{mM} \mathrm{Pi}$ (Fig. 5) and $0-750 \mu \mathrm{M}$ at $32 \mathrm{mM} \mathrm{Pi}$.

ate density centrifugation procedure. Hemolysates were prepared from each fraction, and activities of PP-ribose-P synthetase, hypoxanthine-guanine phosphoribosyltransferase, adenine phosphoribosyltransferase, and glucose-6-phosphate dehydrogenase were determined (Fig. 7). S.M. and normal erythrocytes were comparable in their patterns of hypoxanthineguanine phosphoribosyltransferase, adenine phosphoribosyltransferase, and glucose-6-P dehydrogenase activities relative to increasing erythrocyte density, the latter two activities diminishing with increasing mean erythrocyte specific density as described $(44,45)$. (Increased adenine phosphoribosyltransferase activity in hemolysates from patient S.M. [26] was confirmed in these studies.) PP-ribose-P synthetase in the erythrocytes of normal individuals showed a slight decline in activity with increasing mean cell age, whereas activity of the enzyme in the erythrocytes of patient S.M. was virtually undetectable in all but the least dense erythrocyte population. This study suggested marked instability of PP-ribose-P synthetase in erythrocytes from patient S.M.

Despite the evidence for diminished quantities of active PP-ribose-P synthetase in S.M. erythrocytes, intact, unfractionated erythrocytes from this patient showed increased capacity to synthesize PP-ribose-P at physiological Pi concentration. First, the intracellular PP-ribose-P concentration of freshly isolated S.M. erythrocytes $(5.26 \mathrm{nmol} / \mathrm{ml}$ packed cells) exceeded that of normal erythrocytes $(2.91+0.50 \mathrm{SD})$. The overall increase in PP-ribose-P concentration of S.M. erythrocytes resulted from a much greater PP-ribose-P concentration in the youngest cells from S.M. than in cells of comparable density from normal individuals (12.70 vs. $3.21 \mathrm{nmol} / \mathrm{ml}$ packed cells); in fact, in the most dense erythrocyte fractions, PP-ribose-P concentration in normal cells was $1.92 \mathrm{nmol} / \mathrm{ml}$ packed cells while PP-ribose-P was undetectable in S.M. cells. The higher PP-ribose-P concentration in unfractionated S.M. erythrocytes thus appeared to reflect the distinctly different distributions of S.M. and normal PP-ribose-P synthetase activities demonstrated by the densityfractionation procedure.

Second, intact S.M. erythrocytes showed greater than normal rates of incorporation of labeled adenine (Fig. 8) and hypoxanthine into acid-soluble nucleotides when incubated at $1 \mathrm{mM} \mathrm{Pi}$ but lower than normal rates of incorporation of these labeled bases when in- 

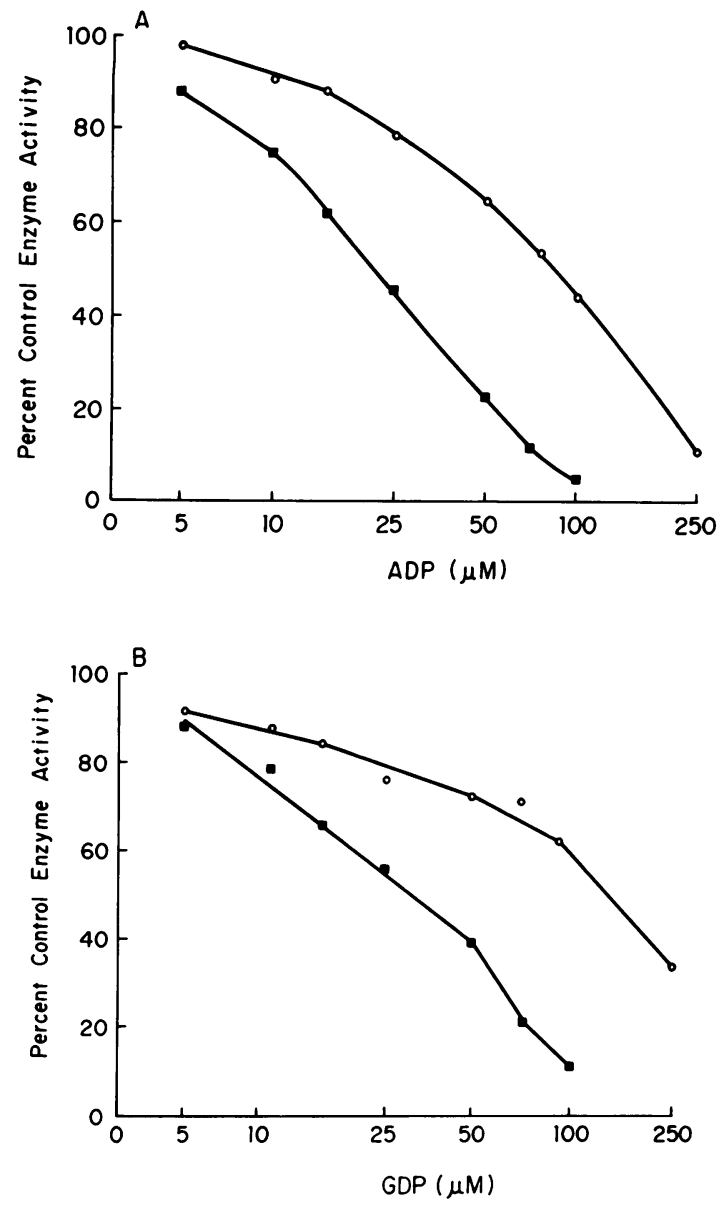

FIGURE 4 Inhibition of partially purified normal $(\square)$ and SM (O) fibroblast PP-ribose-P synthetases by (A) ADP and (B) GDP during incubation at $1 \mathrm{mM} \mathrm{Pi}$. Enzyme activities in partially purified preparations of normal and mutant PPribose-P synthetases (containing equal protein concentrations) were determined during $30 \mathrm{~min}$ incubation at $37^{\circ} \mathrm{C}$ in the presence of the concentrations of inhibitory nucleotides indicated.

cubated at $32 \mathrm{mM} \mathrm{Pi}$. These findings appear to be interpretable in light of the differences between the $\mathrm{Pi}$ activation curves of S.M. and normal erythrocyte PP-ribose-P synthetases (Fig. 6) and the diminished sensitivity of partially purified S.M. erythrocyte PPribose-P synthetase to nucleotide inhibition $\left(\mathrm{I}_{0.5} \mathrm{ADP}\right.$ at $1 \mathrm{mM}$ Pi for normal and S.M. enzymes were 19 and $103 \mu \mathrm{M}$, respectively; $\mathrm{I}_{0.5} \mathrm{GDP}$ at $1 \mathrm{mM} \mathrm{Pi}$ were 36 and $300 \mu \mathrm{M}$, respectively, for normal and S.M. enzymes). That is, at low $\mathrm{Pi}$ concentrations, S.M. enzyme resists the normally profound attenuation of PPribose-P synthetase activity by physiological concentrations of intracellular inhibitors; thus, despite the diminished quantity of active enzyme in the S.M. erythrocyte population, the synthesis of PP-ribose-P proceeds at an increased rate leading to a greater than

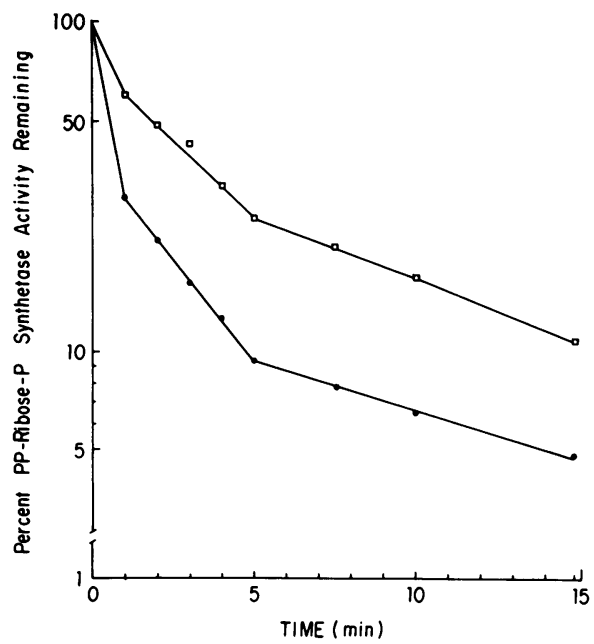

FIGURE 5 Thermal inactivation at $54^{\circ} \mathrm{C}$ of partially purified normal ( $\square$ ) and SM (๑) PP-ribose-P synthetases. Each assay tube contained $4 \mu \mathrm{g}$ of enzyme preparation purified 30 -fold.

normal rate of incorporation of labeled bases into nucleotides. Since, however, at the intracellular $\mathrm{Pi}$ concentration resulting from incubation of cells at 32 $\mathrm{mM} \mathrm{Pi}(2.6 \mathrm{mM}$ Pi for both S.M. and normal erythrocytes), the maximal reaction velocity of S.M. PPribose-P synthetase is not significantly greater than that achieved during incubation at $1 \mathrm{mM} \mathrm{Pi}$ (1.1 and $1.2 \mathrm{mM} \mathrm{Pi}$ for S.M. and normal erythrocytes, respectively), the rates of synthesis of PP-ribose-P by S.M. erythrocytes are similar at both high and low $\mathrm{Pi}$ concentrations. This contrasts with the situation in normal erythrocytes which have a greater quantity of potentially active PP-ribose-P synthetase that is expressed by sigmoidal activation over the range of increasing intracellular Pi concentrations. As a result,

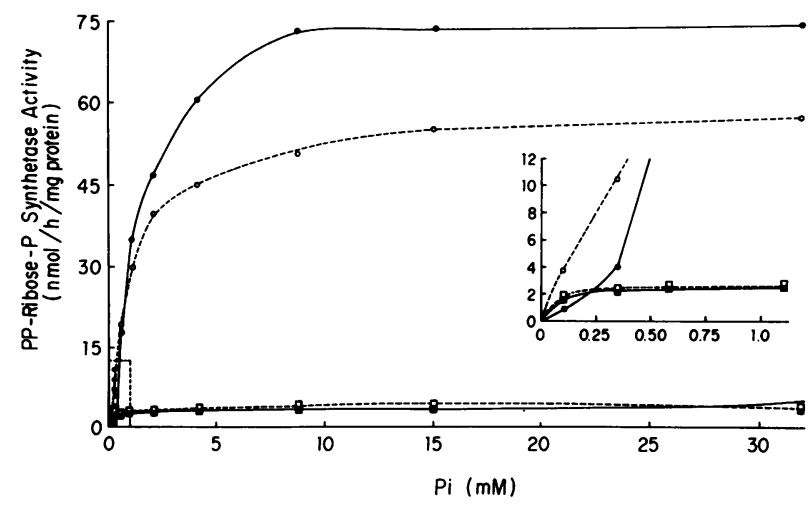

FIGURE 6 Activation of normal and S.M. erythrocyte PP ribose-P synthetases by $\mathrm{Pi}$ in partially dialyzed hemolysates and in hemolysates chromatographed on Sephadex G-25. Inset shows enzyme activation over the range from 0.1 to $1.1 \mathrm{mM}$ $\mathrm{Pi}$ in greater detail. Dialyzed normal hemolysate. (๑); dialyzed S.M. hemolysate, (ם). Chromatographed normal hemolysate, (O); chromatographed S.M. hemolysate. (口). 


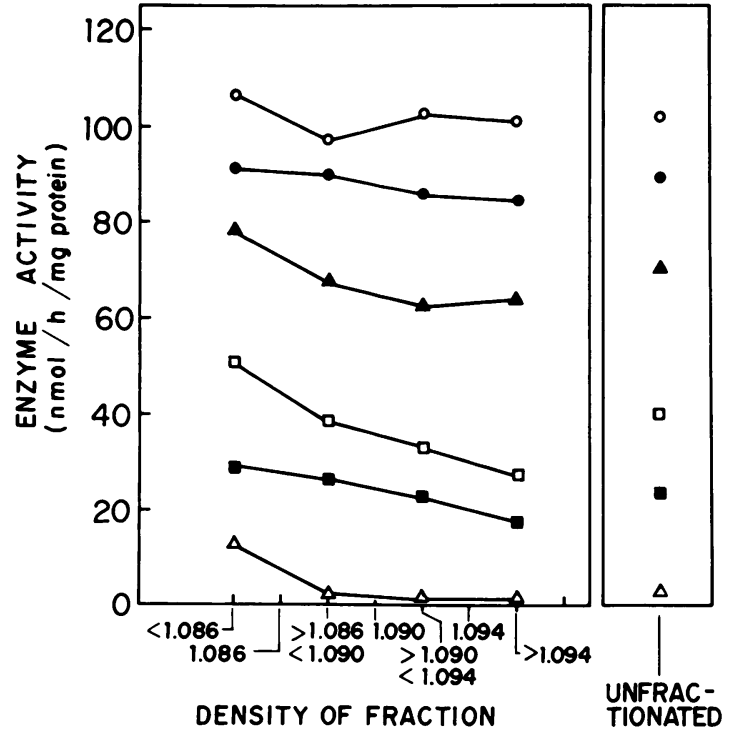

FIGURE 7 Activities of normal (closed symbols) and S.M. (open symbols) PP-ribose-P synthetase $(\triangle)$, adenine phosphoribosyltransferase $(\square)$, and hypoxanthine-guanine phosphoribosyltransferase $(O)$ in hemolysates from unfractionated erythrocytes and hemolysates prepared from erythrocytes fractionated by specific density. Activities of glucose-6phosphate dehydrogenase (not shown) were also determined and were (in order of increasing density): 9.1, 7.3, 5.8 and 4.6 Bücher units per $10^{9}$ normal cells and 8.8, 7.0, 5.8 and 4.4 Bücher units per $10^{9} \mathrm{~S}$.M. cells.

rates of PP-ribose-P synthesis and purine base incorporation by normal erythrocytes are much greater during incubation at $32 \mathrm{mM}$ than at $1 \mathrm{mM} \mathrm{Pi}$ and at the higher concentration, exceed the rates of these processes in S.M. cells.

$P P$-ribose-P synthetase in erythrocytes and fibroblasts from Su.M., mother of patient S.M. Activities of PP-ribose-P synthetase in dialyzed erythrocyte lysates from the mother of S.M. were in the normal range of values for this enzyme at all $\mathrm{Pi}$ concentrations studied, and the $\mathrm{Pi}$ activation curve was sigmoidal. In contrast, evidence for the presence of the abnormal PPribose-P synthetase in cells of Su.M. was obtained by the study of the enzyme in extracts of fibroblasts cultured from this woman. Activities of PP-ribose-P synthetase in dialyzed fibroblast extracts were intermediate between those in normal and S.M. extracts, and hyperbolic $\mathrm{Pi}$ activation of the enzyme was found. In cells harvested from confluent cultures, Su.M. PP-ribose-P synthetase activity at $32 \mathrm{mM} \mathrm{Pi}$ was $740 \mathrm{nmol} / \mathrm{h}$ per $\mathrm{mg}$ protein, a value greater than those of normal cells (range, $285-486 \mathrm{nmol} / \mathrm{h}$ per $\mathrm{mg}$ protein) but less than that of S.M. fibroblasts $(904 \mathrm{nmol} / \mathrm{h}$ per $\mathrm{mg}$ protein). In addition, nucleotide inhibition of PP-ribose-P synthetase activities in Su.M., S.M., and normal fibroblast extracts prepared by Sephadex G-25 chromatography were compared. At $1 \mathrm{mM} \mathrm{Pi}, \mathrm{I}_{0.5}$ of ADP and

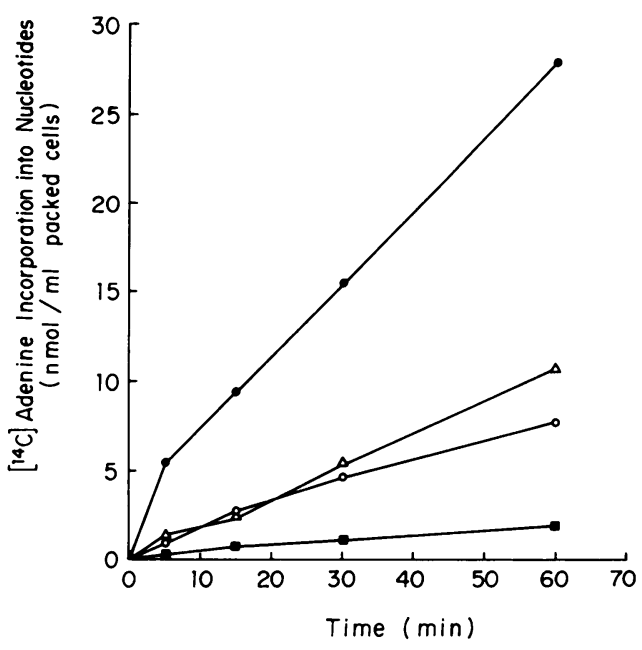

Figure 8 Incorporation of $\left[{ }^{14} \mathrm{C}\right]$ adenine into acid-soluble nucleotides of normal and $S$.M. erythrocytes during incubation at $1 \mathrm{mM}$ and $32 \mathrm{mM} \mathrm{Pi}$. Erythrocytes were suspended in isotonic saline containing the appropriate $\mathrm{Pi}$ concentration. After addition of $\left[8{ }^{14} \mathrm{C}\right]$ adenine (final concentration, $80 \mu \mathrm{M}$ ), incubations were carried out at $37^{\circ} \mathrm{C}$ for the times indicated before perchloric acid extraction and subsequent isolation and counting of labeled nucleotides. Normal cells: at $1 \mathrm{mM} \mathrm{Pi}$,

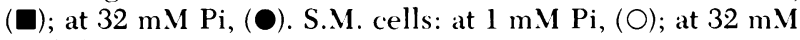
$\mathrm{Pi},(\triangle)$.

GDP for Su.M. PP-ribose-P synthetase were $50 \mu \mathrm{M}$ and $72 \mu \mathrm{M}$, respectively, values intermediate to those for normal and S.M. enzymes (Table II). These studies provide evidence for the presence of the superactive, feedback-resistant form of PP-ribose-P synthetase in the fibroblasts of Su.M., consistent with the hypothesis that this woman is a heterozygous carrier of the aberrant enzyme expressed in hemizygous form by her son, S.M.

\section{DISCUSSION}

The mutant form of PP-ribose-P synthetase characterized in this investigation combines two of the molecular defects previously demonstrated individually to underlie superactivity of this enzyme and result in excessive PP-ribose-P, purine nucleotide and uric acid production in man. PP-ribose-P synthetase from patient S.M. is abnormally resistant to purine nucleotide feedback inhibition of enzyme activity and, in crude or dialyzed enzyme preparations, shows a hyperbolic rather than the normal sigmoidal curve of $\mathrm{Pi}$ activation. In these respects, S.M. PP-ribose-P synthetase resembles the feedback-resistant (regulatory-deficient) enzyme studied in detail by Sperling et al. $(14,16)$ and Zoref et al. (17). In contrast with the findings of these investigators, however, S.M. fibroblast PPribose-P synthetase in crude and dialyzed extracts shows at least twofold greater than normal enzyme activity throughout the entire range of $\mathrm{Pi}$ concentra- 
tions studied, and after Sephadex G-25 chromatography, activity of PP-ribose-P synthetase from S.M. fibroblasts is twice that of normal enzyme at all $\mathrm{Pi}$ concentrations. These findings, together with the demonstration of normal affinity constants of S.M. PP-ribose-P synthetase for MgATP, ribose-5-P and $\mathrm{Mg}^{2+}$, and immunochemical inactivation data showing that S.M. PP-ribose-P synthetase has twofold greater activity per immunoreactive enzyme molecule, are consistent with a catalytic defect in the enzyme resulting in excessive maximal velocity of the enzyme reaction. Thus, S.M. PP-ribose-P synthetase resembles, in this respect, the superactive mutant enzyme with increased maximal velocity described by Becker et al., $(10,18,19)$.

In addition to possessing abnormal regulatory and catalytic properties, S.M. PP-ribose-P synthetase is evidently less stable than the normal enzyme. This instability is manifested in vitro by increased thermal lability of S.M. fibroblast enzyme activity and in vivo both by marked deficiency of enzyme activity at high $\mathrm{Pi}$ concentrations in lysates of unfractionated S.M. erythrocytes and by an accelerated, age-related decrement in enzyme activity in lysates of densityfractionated erythrocytes. Together, the data indicate that the enzyme studied in S.M. is a new variant, distinct from those previously described.

Comparison of PP-ribose-P production in S.M. and normal erythrocytes provides some insight into the process by which PP-ribose-P synthesis in intact cells is ordinarily modulated under physiological conditions of $\mathrm{Pi}$ concentration. Although the in vitro activity of normal erythrocyte PP-ribose-P synthetase was much greater than that of $\mathrm{S} . \mathrm{M}$. enzyme at $1 \mathrm{mM} \mathrm{Pi}$, intracellular PP-ribose-P concentration and the rates of synthesis of purine nucleotides from purine bases at 1 $\mathrm{mM} \mathrm{Pi}$ were greater for S.M. than for normal erythrocytes. Thus, despite evidence for a markedly reduced quantity of mutant PP-ribose-P synthetase in the S.M. erythrocyte population, generation of PP-ribose-P by these cells exceeded generation of this compound by normal cells. This finding is best explained as reflecting the considerable inhibition of intracellular PPribose-P synthesis exerted by nucleotide feedback inhibitors in normal cells at physiological $\mathrm{Pi}$ concentrations $(1,2)$, a regulatory process to which the feedback-resistant S.M. cells are relatively refractory. Mutant cells thus generate PP-ribose-P at an excessive rate despite a reduced amount of enzyme. In a prior study (1), a discrepancy of several hundred-fold between erythrocyte PP-ribose-P synthetase catalytic capacity and PP-ribose-P synthesis was found; our studies confirm at least this much modulation of PPribose-P synthetase activity in the normal cell and provide substantiation of the role of nucleotide inhibitors in accounting, at least in part, for this regulation.
It is tempting to speculate about the relationship between the biochemical consequences of the abnormalities identified in PP-ribose-P synthetase from this family and the clinical findings in the hemizygous male patient, S.M., and his heterozygous mother, Su.M. In contrast with previously described males with superactive PP-ribose-P synthetases $(15,18,20)$ whose uric acid overproduction has resulted in gouty arthritis and/ or uric acid-related renal disease in adulthood, clinical manifestation of hyperuricemia and excessive uric acid excretion occurred in S.M. during the first year of life (26). In addition, a variety of developmental and behavioral abnormalities, including mental retardation and autistic behavior were reported in this patient (26). A recent clinical and psychological reevaluation of S.M. at $14 \mathrm{yr}$ of age has shown a severe sensorineural hearing loss, making an accurate assessment of the reported behavioral abnormalities difficult. Nevertheless, it is of interest that this patient's mother, in whom gout, uric acid urolithiasis and purine overproduction have been documented, shares with her son a significant hearing loss. Whether the combined regulatory and catalytic defects in PPribose-P synthetase in this family account for the early onset of clinical findings in S.M. and the symptomatic expression of the carrier state in Su.M. on the basis of a more severe functional abnormality in $\mathrm{PP}$-ribose-P metabolism than is the case in previously described families or whether additional modifying factors account for these clinical features is uncertain. Similarly, the role of the aberrant enzyme and its metabolic sequelae in the hearing loss of S.M. and Su.M. and the additional developmental and behavioral abnormalities in S.M. require study of additional family members or of families with comparable enzymatic defects.

The results of measurements of PP-ribose-P synthetase activity in erythrocyte lysates from patient S.M. and from his mother have implications pertinent to screening for abnormalities of this enzyme. In the case of patient S.M., initial screening studies at high $\mathrm{Pi}$ concentrations suggested a deficiency of the enzyme which was clearly unexpected in the particular clinical setting. This points out the difficulty in devising a convenient but accurate screening procedure for PPribose-P synthetase. In fact, the range of molecular abnormalities associated to date with superactivity of this enzyme is sufficiently broad $(10,16,17,20)$ that the majority of these variant forms would not have been identified by routine assay procedures.

Although the evidence for X-linkage of the gene for PP-ribose-P synthetase (23-25) is compelling, the use of erythrocyte lysates to identify heterozygous female carriers of superactive variants of the enzyme is unreliable. As previously described $(15,18)$, enzyme 
activities intermediate to those of normal individuals and affected males, as predicted by the Lyon (46) hypothesis, seem to be the exception in erythrocyte lysates from heterozygous carriers of PP-ribose-P synthetase variants. The normal enzyme activity in hemolysates from Su.M. emphasizes this point. Measurement of enzyme activity in fibroblasts cultured from women suspected to carry variant forms of PPribose-P synthetase appears to provide an accurate basis for heterozygote detection $(17,20,24)$, and the availability of cultured fibroblasts provides material for a thorough evaluation of the biochemical consequences of aberrations in this enzyme $(17,18,20)$.

\section{ACKNOWLEDGMENTS}

The authors gratefully acknowledge the expert genetic counseling assistance of Ms. Carolyn Bay, the excellent technical assistance of $\mathrm{Mr}$. Alfred Espinosa and Ms. Cheri Lazar, and the efficient typing of the manuscript by Ms. Maxine Davis.

This work was supported in part by the Medical Research Service of the Veterans Administration, U. S. Public Health Service grants AM-18197 and GM-17702 from the National Institutes of Health; National Foundation-March of Dimes grant 1-377 (Dr. Nyhan); and grants to Dr. J. Edwin Seegmiller from the Kroc Foundation and to Dr. Raivio from the Sigrid Juselius Foundation.

\section{REFERENCES}

1. Hershko, A., A. Razin, and J. Mager. 1969. Regulation of the synthesis of 5-phosphoribosyl-1-pyrophosphate in intact red blood cells and in cell-free preparations. Biochem. Biophys. Acta. 184: 64-76.

2. Bagnara, A. S., A. A. Letter, and J. F. Henderson. 1974. Multiple mechanisms of regulation of purine biosynthesis de novo in intact tumor cells. Biochim. Biophys. Acta. 374: 259-270.

3. Switzer, R. L. 1969. Regulation and mechanism of phosphoribosylpyrophosphate synthetase. I. Purification and properties of the enzyme from Salmonella typhimurium. J. Biol. Chem. 244: 2854-2863.

4. Switzer, R. L. 1971. Regulation and mechanism of phosphoribosylpyrophosphate synthetase. III. Kinetic studies of the reaction mechanism. I. Biol. Chem. 246: 2447-2458.

5. Switzer, R. L., and D. C. Sogin. 1973. Regulation and mechanism of phosphoribosylpyrophosphate synthetase. $V$. Inhibition by end products and regulation by adenosine diphosphate. J. Biol. Chem. 248: 1063-1073.

6. Wong, P. C. L., and A. W. Murray. 1969. 5-Phosphoribosyl pyrophosphate synthetase from Ehrlich ascites tumor cells. Biochemistry. 8: 1608-1614.

7. Fox, I. H., and W. N. Kelley. 1972. Human phosphoribosylpyrophosphate synthetase. Kinetic mechanism and end product inhibition. J. Biol. Chem. 247: 2126-2131.

8. Roth, D. G., E. Shelton, and T. F. Deuel. 1974. Purification and properties of phosphoribosylpyrophosphate synthetase from rat liver. J. Biol. Chem. 249: 291-296.

9. Roth, D. G., and T. F. Deuel. 1974. Stability and regulation of phosphoribosylpyrophosphate synthetase from rat liver. J. Biol. Chem. 249: 297-301.

10. Becker, M. A., P. J. Kostel, and L. J. Meyer. 1975. Human phosphoribosylpyrophosphate synthetase. Comparison of purified normal and mutant enzymes. J. Biol. Chem. 250: $6822-6830$.

11. Fox, I. H., and W. N. Kelley. 1971. Human phosphoribosylpyrophosphate synthetase. Distribution, purification and properties. J. Biol. Chem. 246: 5739-5748.

12. Becker, M. A., L. J. Meyer, W. H. Huisman, C. Lazar, and W. B. Adams. 1977. Human erythrocyte phosphoribosylpyrophosphate synthetase. Subunit analysis and states of subunit association. J. Biol. Chem. 252: $3911-$ 3918.

13. Meyer, L. J., and M. A. Becker. 1977. Human erythrocyte phosphoribosylpyrophosphate synthetase. Dependence of activity on state of subunit association. J. Biol. Chem. 252: 3919-3925.

14. Sperling, O., P. Boer, S. Persky-Brosh, E. Kanarek, and A. deVries. 1972. Altered kinetic property of erythrocyte phosphoribosylpyrophosphate synthetase in excessive purine production. Rev. Eur. Etud. Clin. Biol. 17: 703-706.

15. Sperling, O., G. Eilam, S. Persky-Brosh, and A. De Vries. 1972. Accelerated 5-phosphoribosyl-1-pyrophosphate synthesis. A familial abnormality associated with excessive uric acid production and gout. Biochem. Med. 6: 310316.

16. Sperling, O., S. Persky-Brosh, P. Boer, and A. de Vries. 1973. Human erythrocyte phosphoribosylpyrophosphate synthetase mutationally altered in regulatory properties. Biochem. Med. 7: 389-395.

17. Zoref, E., A. de Vries, and O. Sperling. 1975. Mutant feedback resistant phosphoribosylpyrophosphate synthetase associated with purine overproduction and gout. J. Clin. Invest. 56: 1093-1099.

18. Becker, M. A., L. J. Meyer, and J. E. Seegmiller. 1973. Gout with purine overproduction due to increased phosphoribosylpyrophosphate synthetase activity. Am.J.Med. 55: 232-242.

19. Becker, M. A., P. J. Kostel, L. J. Meyer, and J. E. Seegmiller. 1973. Human phosphoribosylpyrophosphate synthetase: increased enzyme specific activity in a family with gout and excessive purine synthesis. Proc. Natl. Acad. Sci. U. S. A. 70: 2749-2752.

20. Becker, M. A. 1976. Patterns of phosphoribosylpyrophosphate and ribose-5-phosphate concentration and generation in fibroblasts from patients with gout and purine overproduction. J. Clin. Invest. 57: 308-318.

21. Fox, I. H., and W. N. Kelley. 1971. Phosphoribosylpyrophosphate in man: biochemical and clinical significance. Ann. Intern. Med. 74: 424-433.

22. Becker, M. A. 1978. Abnormalities of PRPP metabolism leading to an overproduction of uric acid. In Uric Acid. W. N. Kelley and I. M. Weiner, editors. Handbook of Experimental Pharmacology, Springer-Verlag, BerlinHeidelberg-New York, Heidelberg, West Germany. 51: $155-183$.

23. Zoref, E., A. de Vries, and O. Sperling 1977. X-linked pattern of inheritance of gout due to mutant feedbackresistant phosphoribosylpyrophosphate synthetase. Adv. Exp. Med. Biol. 76A: 287-292.

24. Yen, R. C. K., W. B. Adams, C. Lazar, and M. A. Becker. 1978. Evidence for X-linkage of human phosphoribosylpyrophosphate synthetase. Proc. Natl. Acad. Sci. U. S. A. 75: $482-485$.

25. Becker, M. A., R. C. K. Yen, P. Itkin, S. J. Goss, J. E. Seegmiller, and B. Bakay. 1979. Regional localization of the gene for human phosphoribosylpyrophosphate synthetase 
on the X-chromosome. Science (Wash. D. C.). 203: 10161019.

26. Nyhan, W. L., J. A. Jones, A. J. Teberg, L. Sweetman, and L. G. Nelson. 1969. A new disorder of purine metabolism with behavioral manifestations. J. Pediatr. 74: 20-27.

27. Rosenbloom, F. M., J. F. Henderson, I. C. Caldwell, W. N. Kelley, and J. E. Seegmiller. 1968. Biochemical bases of accelerated purine biosynthesis de novo in human fibroblasts lacking hypoxanthine-guanine phosphoribosyltransferase. J. Biol. Chem. 243: 1166-1173.

28. Lowry, O. H., N. J. Rosebrough, A. L. Farr, and R. J. Randall. 1951. Protein measurement with Folin phenol reagent. J. Biol. Chem. 193: 265-275.

29. Henderson, J. F. 1962. Feedback inhibition of purine biosynthesis in ascites tumor cells. J. Biol. Chem. 237: 2631-2635.

30. Kelley, W. N., M. L. Greene, F. M. Rosenbloom, J. F. Henderson, and J. E. Seegmiller, 1969. Hypoxanthineguanine phosphoribosyltransferase deficiency in gout. Ann. Intern. Med. 70: 155-206.

31. Boyle, J. A., K. O. Raivio, M. A. Becker, and J. E. Seegmiller. 1972. Effects of nicotinic acid on human fibroblast purine synthesis Biochim. Biophys. Acta. 269: $179-183$.

32. Kelley, W. N., and J. C. Meade. 1971. Studies on hypoxanthine-guanine phosphoribosyltransferase in fibroblasts from patients with the Lesch-Nyhan syndrome. Evidence for genetic heterogeneity. J. Biol. Chem. 246: 2953-2958.

33. Kelley, W. N. 1971. Studies on the adenine phosphoribosyltransferase enzyme in human fibroblasts lacking hypoxanthine-guanine phosphoribosyltransferase.J. Lab. Clin. Med. 77: 33-38.

34. Raivio, K. O., and J. E. Seegmiller. 1973. Adenine, hypoxanthine and guanine metabolism in fibroblasts from normal individuals and patients with hypoxanthine phosphoribosyltransferase deficiency. Biochim. Biophys. Acta. 299: 273-282.
35. Henderson, J. F., and M. K. Y. Khoo. 1965. Availability of 5-phosphoribosyl 1-pyrophosphate for ribonucleotide synthesis in Ehrlich ascites tumor cells in vitro. J. Biol. Chem. 240: 2358-2362.

36. Henderson, J. F., F. M. Rosenbloom, W. N. Kelley, and J. E. Seegmiller. 1968. Variations in purine metabolism of cultured skin fibroblasts from patients with gout.J. Clin. Invest. 47: 1511-1516.

37. Johnson, M. G., S. Rosenzweig, R. L. Switzer, M. A. Becker, and J. E. Seegmiller. 1974. Evaluation of the role of 5-phosphoribosyl-1-pyrophosphate synthetase in congenital hyperuricemia and gout. A simple isotopic assay and an activity stain for the enzyme. Biochem. Med. 10: $266-275$.

38. Kelley, W. N., F. M. Rosenbloom, J. F. Henderson, and J. E. Seegmiller. 1967. A specific enzyme defect in gout associated with overproduction of uric acid. Proc. Natl. Acad. Sci. U. S. A. 57: 1735-1739.

39. Simmons, A. 1976. Technical Hematology. 2nd Edition. J. B. Lippincott Co., Philadelphia. 157-159.

40. Chen, P. S., Jr., T. Y. Toribara, and H. Warner. 1956. Anal. Chem. 28: 1756-1758.

41. Beardmore, T. D., J. S. Cashman, and W. N. Kelley. 1972. Mechanism of allopurinol-mediated increase in enzyme activity in man. J. Clin. Invest. 51: 1823-1832.

42. Danon, D., and Y. Marikovsky. 1964. Determinations of density distribution of red cell population. J. Lab Clin. Med. 64: 668-674.

43. Martin, D. W., Jr., and Maler, B. A. 1976. Phosphoribosylpyrophosphate synthetase is elevated in fibroblasts from patients with the Lesch-Nyhan syndrome. Science (Wash. D. C.). 193: 408-411.

44. Rubin, C. S., M. E. Balis, S. Piomelli, P. H. Berman, and J. Dancis. 1969. J. Lab. Clin. Med. 74: 732-741.

45. Marks, P. A., A. B. Johnson, and E. Hirschberg. 1958. Effect of age on the enzyme activity in erythrocytes. Proc. Natl. Acad. Sci. U. S. A. 44: 529-536.

46. Lyon, M. F. 1961. Gene action in the X-chromosome of the mouse. Nature (Lond.). 190: 373. 